\title{
Varietal Evaluation of Potato Microtuber and Plantlet in Seed Tuber Production
}

\author{
Md. Sadek Hossain, ${ }^{1}$ M. Mofazzal Hossain, ${ }^{2}$ M. Moynul Haque, ${ }^{3}$ \\ Md. Mahabubul Haque, ${ }^{4}$ and Md. Dulal Sarkar ${ }^{5}$ \\ ${ }^{1}$ Seed Distribution Division, Bangladesh Agricultural Development Corporation, Dhaka, Bangladesh \\ ${ }^{2}$ Department of Horticulture, Bangabandhu Sheikh Mujibur Rahman Agricultural University, Gazipur 1703, Bangladesh \\ ${ }^{3}$ Department of Agronomy, Bangabandhu Sheikh Mujibur Rahman Agricultural University, Gazipur 1703, Bangladesh \\ ${ }^{4}$ Farm Division, Bangladesh Agricultural Research Institute, Gazipur, Bangladesh \\ ${ }^{5}$ Department of Horticulture, Sher-e-Bangla Agricultural University, Dhaka 1207, Bangladesh
}

Correspondence should be addressed to Md. Dulal Sarkar; dulalsau_121@yahoo.com

Received 28 December 2016; Revised 12 February 2017; Accepted 14 February 2017; Published 5 March 2017

Academic Editor: Maria Serrano

Copyright ( 2017 Md. Sadek Hossain et al. This is an open access article distributed under the Creative Commons Attribution License, which permits unrestricted use, distribution, and reproduction in any medium, provided the original work is properly cited.

\begin{abstract}
Diamant, Asterix, and Granola varieties differed significantly in foliage coverage, plant height, and yield. They produced lower graded minituber $\left(67.62 \%, 78.16 \% \mathrm{ha}^{-1}\right.$, and $66.27 \%$ of Asterix, Granola, and Diamant varieties, resp.) as per seed rule of the National Seed Board of Bangladesh, while foliage coverage (74.38\%) was the maximum in Diamant. Microtuber in field condition showed the maximum survivability, plant height, foliage coverage, number of stems plant ${ }^{-1}$, and SPAD value as well as yield of minituber compared to plantlet. On the contrary, microtuber derived plants of the three varieties gave the maximum yield $\left(20.49 \mathrm{tha}^{-1}\right.$, $19.12 \mathrm{t} / \mathrm{ha}^{-1}$, and $19.98 \mathrm{tha}^{-1}$ of Asterix, Granola, and Diamant varieties, resp.) and it was the minimum in plants of plantlets derived from all varieties $\left(9.50 \mathrm{t} \mathrm{ha}^{-1}, 7.88 \mathrm{tha}^{-1}\right.$, and $9.70 \mathrm{t} \mathrm{ha}^{-1}$ of Asterix, Granola, and Diamant varieties, resp.). Microtuber derived plants produced a minimum percentage of $<28 \mathrm{~mm}$ size of minituber compared to plantlet derived plants in case of all varieties.
\end{abstract}

\section{Introduction}

Potato (Solanum tuberosum L.) is a winter vegetable crop mainly in Bangladesh [1]. Ideal production protocols are wanted regarding microtuber induction and development, especially for Bangladeshi potato cultivars. Also, their comparative growth and yield efficiency study is the consensus at open field condition in relation to other propagules for minituber or seed tuber production. Utilization of microtubers for the speedy proliferation of seed tuber is becoming an important technique [2]. There is significant uncertainty regarding the utility of microtubers for evaluation of agronomic characters to the commercial growers. However, the application of microtubers in germplasm conservation is extensively recognized. Microtubers in different grades have different dormancy requirements and differ widely in relative growth potential and productivity. Again, the key problems of traditional seed tuber production systems are the stumpy growth rate of field-grown potatoes and the susceptibility to viral, bacterial, or fungal diseases increases with field multiplication, which are conveyed to progeny through the seed tubers. This is especially significant because the countries are unable to produce high-quality potato seed tubers [3-5]. In recent years, alternative seed production program has been developed in which the first multiplication steps are speeded up by using in vitro plantlets [6-8], microtubers [9-11], and minitubers [12]. Microtubers are particularly convenient for handling, storage, and transportation of germplasm and for the development of disease-free materials $[9,13]$. Microtuber needs to grow at least once and preferably two or three times under protected or field conditions to produce desired lot of quality seed [14]. Although there are some protocols for in vitro microtuberization, there is also no comparative information regarding their field performance especially for Bangladeshi potato cultivars. So the usefulness of microtubers will be contingent on their yield potentiality under open 
field conditions. Therefore, the present study was undertaken to evaluate the field performance of in vitro microtuber in comparison with in vitro plantlets.

\section{Materials and Methods}

2.1. Experimental Site. The experiment was conducted at Bangabandhu Sheikh Mujibur Rahman Agricultural University during the period from November 2012 to March 2013. The location of the experimental site was $24.09^{\circ} \mathrm{N}$ latitude and $90.26^{\circ} \mathrm{E}$ longitude with an elevation of $8.2 \mathrm{~m}$ above sea level.

2.2. Seed Source. Diseases-free in vitro plantlets of three potato varieties, namely, Asterix, Granola, and Diamant, were collected from Bangladesh Agricultural Research Institute and Bangladesh Agricultural Development Corporation Tissue Culture Laboratory which were prepared through meristem culture earlier.

2.3. In Vitro Multiplication of Plantlets. In vitro plantlets of three potato varieties were multiplied as per routine by subculturing of single-stem nodes at every three weeks' interval for growing the explants 68-node stage for experimentation. The multiplication medium contained minerals, salts, and vitamins [15] which were supplemented with $0.1 \mathrm{mgl}^{-1}$ Gibberellic acid $\left(\mathrm{GA}_{3}\right), 0.01 \mathrm{mgl}^{-1}$ naphthaleneacetic acid (NAA), $4 \mathrm{mgl}^{-1} \mathrm{D}$-calcium pantothenate, and $30 \mathrm{gl}^{-1}$ sucrose. The medium was solidified with $8 \mathrm{gl}^{-1}$ agar and $\mathrm{pH}$ was adjusted to 5.7 prior to autoclaving. The temperature in the growth chamber was $20 \pm 1^{\circ} \mathrm{C}$ with 16 hour photoperiod and the light was supplied by fluorescent tubes at an intensity of 3000 Lux.

\subsection{In Vitro Production of Microtuber}

2.4.1. Step I. Eight stem segments (each with 3 nodes) of in vitro subcultured plantlets were again cultured in liquid medium in $250 \mathrm{~mL}$ Erlenmeyer flasks containing mineral salts and vitamins [15] supplemented with $0.1 \mathrm{mgl}^{-1} \mathrm{GA}_{3}$, $0.01 \mathrm{mgl}^{-1} \mathrm{NAA}, 4 \mathrm{mgl}^{-1} \mathrm{D}$-calcium pantothenate, and $30 \mathrm{gl}^{-1}$ sucrose for 28 days.

2.4.2. Step II. After 28 days, the liquid media were decanted off and $40 \mathrm{~mL}$ microtuber induction medium based on MS medium [15] was supplemented with $10 \mathrm{mgl}^{-1}$ benzyl adenine (BA) and different concentrations of sucrose $(0,3$, $4,6,8,10,12$, and 14\%). Then the microtuber induction cultures were incubated in the dark at $20^{\circ} \mathrm{C}$ [16]. All cultures in Erlenmeyer flask were closed with a cotton cap.

2.5. Harvest of Microtuber. Cultures with microtuber were kept in full light after 63 days of incubation for greening. After 70 days of incubation, microtubers were harvested aseptically and washed properly and then treated with Bavistin. Those microtubers were stored in a refrigerator at $4^{\circ} \mathrm{C}$ temperature.

2.6. Propagule Preparation. 21-day-old in vitro rooted plantlets were removed from culture and washed to remove agar and treated with fungicides. The plantlets were kept for 48 hours in poly bags for hardening and after that plantlets were planted in the field. At the same time, fungicide treated sprouted microtubers $(>250 \mathrm{mg}$ ) were planted in the field. Watering was done to keep the soil moist accordingly. Pseudostem of banana was used as mulch every day from 9:00 am to 3:00 pm for 10 days to protect the plantlets and sprouted microtubers from direct sunshine after planting.

2.7. Treatments and Design of the Experiment. The factorial experiment was designed as a randomized complete block design with four replications. Treatments were consisting of microtuber and in vitro plantlets of three varieties, namely, Asterix, Granola, and Diamant. Those were planted at $60 \mathrm{~cm} \times$ $25 \mathrm{~cm}$ spacing and plot size was $1.8 \mathrm{~m} \times 2.0 \mathrm{~m}$.

2.8. Land Preparation and Planting of Propagules. The propagules were planted on 1 December in the field. The soil of the plot was light clay loam supplemented with well rotten cow dung. The entire doses of $\mathrm{Ca}\left(\mathrm{H}_{2} \mathrm{PO}_{4}\right)_{2}(220 \mathrm{~kg} / \mathrm{ha})$, $\mathrm{KCl}(270 \mathrm{~kg} / \mathrm{ha}), \mathrm{CaSO}_{4} \cdot 2 \mathrm{H}_{2} \mathrm{O}(120 \mathrm{~kg} / \mathrm{ha}), \mathrm{ZnSO}_{4}(5 \mathrm{~kg} / \mathrm{ha})$, and $50 \% \mathrm{CO}\left(\mathrm{NH}_{2}\right)_{2}(180 \mathrm{~kg} / \mathrm{ha})$ were made at the time of land preparation. The remaining portion of $\mathrm{CO}\left(\mathrm{NH}_{2}\right)_{2}$ $(180 \mathrm{~kg} / \mathrm{ha})$ was side-dressed at the time of last earthing-up [17]. Intercultural operations like earthing-up and weeding were done as and when required. The experimental plots were irrigated frequently to maintain adequate soil moisture and also to keep the soil cool. Secure and Dimecron were sprayed to protect the crop from late blight and aphid infestation, respectively.

2.9. Collection of Data. Data were collected on plant stand at 45 days after planting and foliage coverage (\%) at 45 days after planting and plant height $(\mathrm{cm})$, stem plant ${ }^{-1}$, number of minitubers plant ${ }^{-1}$, yield of minitubers plant ${ }^{-1}(\mathrm{~g})$, yield of minitubers ( $\mathrm{t} \mathrm{ha}^{-1}$ ), and the grade of minitubers (\%) were collected during harvest at 90 days after planting.

Analysis of Data. All the collected data were analyzed by analysis of variance and the means were compared according to Duncan's Multiple Range Test at 5\% level of probability.

\section{Results and Discussion}

3.1. Varietal Performance of Potato in Field Condition. The varieties did not vary significantly in plant stand at 45 DAP, stems plant $^{-1}$, SPAD value, and number of minitubers plant ${ }^{-1}$ (Table 1). They differed significantly in foliage coverage, plant height, yield of minitubers plant ${ }^{-1}$, and yield of minitubers $\left(\mathrm{tha}^{-1}\right)$. Zakaria [18] found no significant difference in main stems plant ${ }^{-1}$ and plant stand at $45 \mathrm{DAP}$, while there were significant differences in the number of tubers plant ${ }^{-1}$. Foliage coverage $(74.38 \%)$ was the maximum in Diamant, while plant height, yield of minitubers plant ${ }^{-1}$, and yield of minitubers $\left(\mathrm{tha}^{-1}\right)$ were statistically similar to the variety Asterix. All of the three varieties produced lower graded minituber as per seed rule of NSB, while Diamant and Asterix 
TABLE 1: Varietal performance of potato in field condition.

\begin{tabular}{|c|c|c|c|c|c|c|c|c|}
\hline Variety & $\begin{array}{l}\text { Plant stand } \\
(\%) \text { at } 45 \\
\text { DAP }\end{array}$ & $\begin{array}{c}\text { Foliage } \\
\text { coverage }(\%) \\
\text { at } 45 \text { DAP }\end{array}$ & $\begin{array}{c}\text { Plant height } \\
(\mathrm{cm}) \text { at } 90 \\
\text { DAP }\end{array}$ & $\begin{array}{c}\text { Number of } \\
\text { main stems } \\
\text { plant }^{-1} \text { at } 90 \\
\text { DAP }\end{array}$ & $\begin{array}{l}\text { SPAD value of } \\
\text { leaves at } 90 \text { DAP }\end{array}$ & $\begin{array}{c}\text { Number of } \\
\text { minitubers } \\
\text { plant }^{-1} \text { at } 90 \\
\text { DAP }\end{array}$ & $\begin{array}{c}\text { Yield of } \\
\text { minitubers ( } \mathrm{g} \\
\text { plant }^{-1} \text { ) at } 90 \\
\text { DAP }\end{array}$ & $\begin{array}{c}\text { Yield of } \\
\text { minitubers } \\
\left(\mathrm{t} \mathrm{ha}^{-1}\right) \text { at } 90 \\
\text { DAP }\end{array}$ \\
\hline Asterix & 92.7 & $66.25^{\mathrm{b}}$ & $32.25^{\mathrm{a}}$ & 2.00 & 51.55 & 13.11 & $224.90^{\mathrm{a}}$ & $14.99^{\mathrm{a}}$ \\
\hline Granola & 88.5 & $52.13^{c}$ & $30.34^{\mathrm{b}}$ & 1.88 & 52.42 & 13.47 & $202.50^{\mathrm{b}}$ & $13.50^{\mathrm{b}}$ \\
\hline Diamant & 90.6 & $74.38^{\mathrm{a}}$ & $31.63^{\mathrm{ab}}$ & 2.00 & 50.25 & 14.26 & $222.10^{\mathrm{a}}$ & $14.84^{\mathrm{a}}$ \\
\hline
\end{tabular}

Means followed by same letter(s) in a column are not significantly different by DMRT at 5\% level of probability.

TABLE 2: Planting materials influencing potato production in field condition.

\begin{tabular}{|c|c|c|c|c|c|c|c|c|}
\hline Treatments & $\begin{array}{l}\text { Plant stand } \\
(\%) \text { at } 45 \\
\text { DAP }\end{array}$ & $\begin{array}{c}\text { Foliage } \\
\text { coverage }(\%) \\
\text { at } 45 \mathrm{DAP}\end{array}$ & $\begin{array}{c}\text { Plant height } \\
(\mathrm{cm}) \text { at } 90 \\
\text { DAP }\end{array}$ & $\begin{array}{c}\text { Number of } \\
\text { main stems } \\
\text { plant }^{-1} \text { at } 90 \\
\text { DAP }\end{array}$ & $\begin{array}{c}\text { SPAD value } \\
\text { of leaves at } 90 \\
\text { DAP }\end{array}$ & $\begin{array}{c}\text { Number of } \\
\text { minitubers } \\
\text { plant }^{-1} \text { at } 90 \\
\text { DAP }\end{array}$ & $\begin{array}{c}\text { Yield of } \\
\text { minitubers (g } \\
\text { plant }^{-1} \text { ) at } 90 \\
\text { DAP }\end{array}$ & $\begin{array}{c}\text { Yield of } \\
\text { minitubers } \\
\left(\mathrm{t} \mathrm{ha}^{-1}\right) \text { at } 90 \\
\text { DAP }\end{array}$ \\
\hline Microtuber & 97.23 & 72.50 & 38.43 & 2.50 & 52.08 & 12.59 & 297.94 & 19.86 \\
\hline Plantlet & 84.02 & 56.00 & 24.39 & 1.42 & 50.748 & 14.64 & 135.08 & 9.03 \\
\hline$\overline{S E}$ & 1.49 & 1.11 & 0.56 & 0.14 & 0.61 & 0.3866 & 4.94 & 0.34 \\
\hline
\end{tabular}

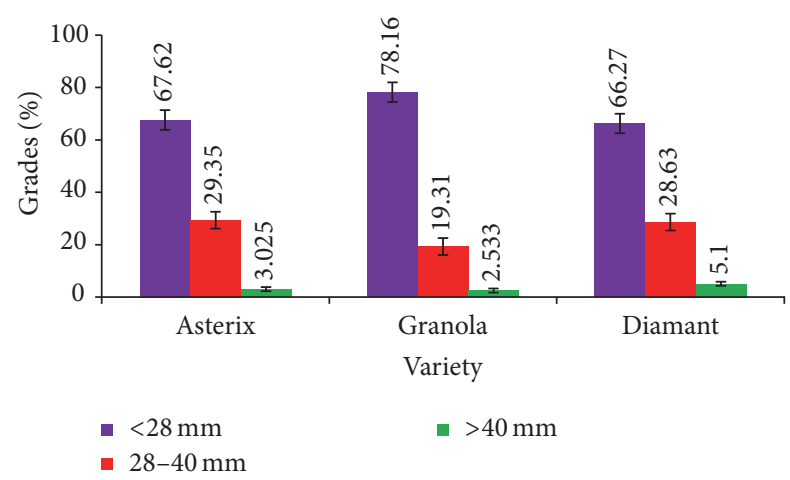

FIGURE 1: Varietal performance on minituber grades according to size.

produced a higher percentage of $28-40 \mathrm{~mm}$ grade minituber than Granola (Figure 1).

\subsection{Performance of Potato Microtuber and Plantlet in} Field Condition. Planting materials widely varied from one another regarding plant stand at 45 DAP (Table 2). Plants derived from microtuber sharply showed the maximum survivability, plant height, foliage coverage, number of stems plant $^{-1}$, and SPAD value as well as yield of minituber compared to plant derived from plantlet in field condition, while the number of minitubers plant ${ }^{-1}$ was more in plantlets derived plants than in microtuber derived plants. Kawakami et al. [19] reported that, unlike micropropagated plantlets, microtubers do not require time-consuming hardening periods in greenhouses and can be handled much like normal seed tubers. These have the potential to be used for field planting as the fresh tuber yields from microtuber plants were $82 \%$ that of conventional tuber plants. Pérez-Alonso et al. [20] reported also that, fifteen days after field planting,

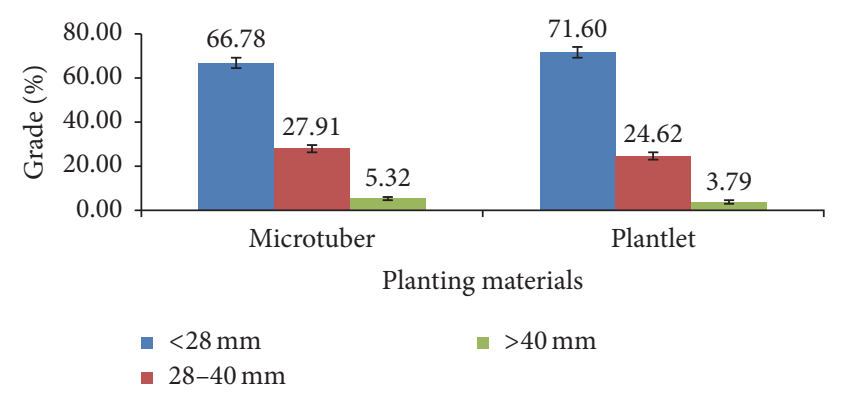

FIGURE 2: Effect of planting materials on production of minituber grades according to size.

$89 \%$ of the microtubers sprouted and subsequently produced vigorous plants, whereas plants derived from microtuber of the cardinal variety showed about $85 \%$ survivability [21], with minimum foliage coverage with in vitro plantlets [22]. Microtubers produced a relatively higher number of stems plant $^{-1}$ and yield plant ${ }^{-1}$ compared to plantlets [23]. Microtubers produced a higher number of middle-grade minitubers than plantlet derived plants and also produced a similar number of minitubers of $<28 \mathrm{~mm}$ grade, but the minituber was heavier compared to plantlet derived plant (Figure 2). Microtubers and minitubers produced statistically similar yields [18]. Dodds et al. [24] concluded that in vitro microtubers behave similarly to in vitro plantlets with the advantage of being easy to handle and show more resistance to stressful environmental conditions. So current findings agreed with them.

\subsection{Interaction Effect of Variety and Planting Materials of} Potato in Field Condition. Microtubers of all the three varieties had the highest plant stand at 45 DAP compared to the plant stands of plantlet derived plants and the lowest plant 
TABLE 3: Interaction effect of variety and planting materials in field condition.

\begin{tabular}{|c|c|c|c|c|c|c|c|c|c|}
\hline \multicolumn{2}{|c|}{ Treatments } & $\begin{array}{c}\text { Plant } \\
\text { stand (\%) } \\
\text { at } 45 \text { DAP }\end{array}$ & $\begin{array}{c}\text { Foliage } \\
\text { coverage } \\
(\%) \text { at } 45 \\
\text { DAP }\end{array}$ & $\begin{array}{l}\text { Plant height } \\
(\mathrm{cm}) \text { at } 90 \\
\text { DAP }\end{array}$ & $\begin{array}{c}\text { Number of } \\
\text { main stems } \\
\text { plant }^{-1} \text { at } 90 \\
\text { DAP }\end{array}$ & $\begin{array}{c}\text { SPAD value } \\
\text { of leaves at } 90 \\
\text { DAP }\end{array}$ & $\begin{array}{c}\text { Number of } \\
\text { minitubers } \\
\text { plant }^{-1} \text { at } 90 \\
\text { DAP }\end{array}$ & $\begin{array}{c}\text { Yield of } \\
\text { minitubers } \\
\left(\mathrm{g} \text { plant }{ }^{-1}\right) \\
\text { at } 90 \mathrm{DAP}\end{array}$ & $\begin{array}{c}\text { Yield of } \\
\text { minitubers } \\
\left(\mathrm{t} \mathrm{ha}^{-1}\right) \text { at } 90 \\
\text { DAP }\end{array}$ \\
\hline \multirow{2}{*}{ Asterix } & Microtuber & $97.93^{\mathrm{a}}$ & $70.00^{\mathrm{b}}$ & $40.13^{\mathrm{a}}$ & $2.50^{\mathrm{a}}$ & $52.07^{\mathrm{ab}}$ & $11.93^{\mathrm{c}}$ & $307.30^{\mathrm{a}}$ & $20.49^{\mathrm{a}}$ \\
\hline & Plantlet & $87.50^{\mathrm{b}}$ & $62.50^{\mathrm{c}}$ & $24.38^{\mathrm{c}}$ & $1.50^{\mathrm{b}}$ & $51.03^{\mathrm{ab}}$ & $14.30^{\mathrm{ab}}$ & $142.5^{\mathrm{b}}$ & $9.50^{\mathrm{b}}$ \\
\hline \multirow{2}{*}{ Granola } & Microtuber & $95.85^{\mathrm{a}}$ & $65.00^{\mathrm{bc}}$ & $35.38^{\mathrm{b}}$ & $2.50^{\mathrm{a}}$ & $52.85^{\mathrm{a}}$ & $12.46^{\mathrm{bc}}$ & $299.7^{\mathrm{a}}$ & $19.12^{\mathrm{a}}$ \\
\hline & Plantlet & $81.23^{\mathrm{b}}$ & $39.25^{\mathrm{d}}$ & $25.31^{\mathrm{c}}$ & $1.25^{\mathrm{b}}$ & $52.00^{\mathrm{ab}}$ & $14.49^{\mathrm{ab}}$ & $118.2^{\mathrm{b}}$ & $7.88^{\mathrm{b}}$ \\
\hline \multirow{2}{*}{ Diamant } & Microtuber & $97.94^{\mathrm{a}}$ & $82.50^{\mathrm{a}}$ & $39.78^{\mathrm{a}}$ & $2.50^{\mathrm{a}}$ & $51.30^{\mathrm{ab}}$ & $13.39^{\mathrm{abc}}$ & $286.8^{\mathrm{a}}$ & $19.98^{\mathrm{a}}$ \\
\hline & Plantlet & $83.32^{\mathrm{b}}$ & $66.25^{\mathrm{bc}}$ & $23.48^{\mathrm{c}}$ & $1.50^{\mathrm{b}}$ & $49.20^{\mathrm{b}}$ & $15.14^{\mathrm{a}}$ & $144.5^{\mathrm{b}}$ & $9.70^{\mathrm{b}}$ \\
\hline
\end{tabular}

Means followed by same letter(s) in a column are not significantly different by DMRT at $5 \%$ level of probability.

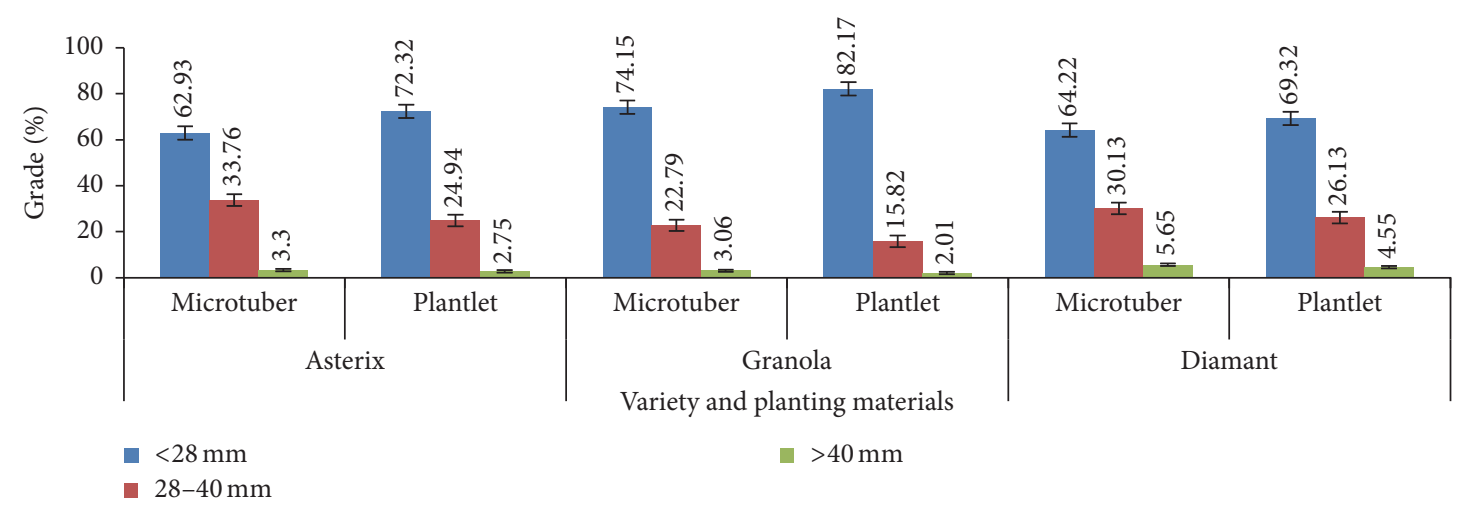

FIGURE 3: Interaction effects of variety and planting materials of potato on minituber grades according to size.

stand was observed in plantlets derived plants of Granola which was statistically similar with Diamant for the trait (Table 3). The plant height was biggest $(40.13 \mathrm{~cm})$ in the plants propagated from microtubers of Asterix which was statistically similar to Diamant followed by microtuber propagated plants of Granola, while all the three varieties produced short plants in plantlets propagated plants (Table 3). Main stems plant $^{-1}$ also were higher in microtuber derived plants than those derived from in vitro plantlet (Table 3). SPAD value was statistically the same in both planting materials derived plants except plants of plantlet derived from Diamant (Table 3). The in vitro plantlets of the variety Diamant produced the maximum number of minitubers plant ${ }^{-1}$ and it was statistically similar with minitubers plant ${ }^{-1}$ of Asterix and Granola of the same planting materials. Again, statistically, the number of minitubers plant ${ }^{-1}$ was lowest in those plants which are derived from microtuber in case for all varieties (Table 3). On the contrary, yield of minitubers plant ${ }^{-1}$ (g) was the highest in plants which are derived from microtuber in case for all varieties. Microtuber derived plants of the three varieties gave the maximum yield of minitubers (20.49, 19.12, and $19.98 \mathrm{tha}^{-1}$ of Asterix, Granola, and Diamant varieties, resp.) and it was the minimum in plantlets derived plants of all varieties $\left(9.50,7.88\right.$, and $9.70 \mathrm{tha}^{-1}$ of Asterix, Granola, and Diamant varieties, resp.) (Table 3). Zakaria [18] reported that in vitro plantlets showed very poor yield performance regarding minituber or normal seed tuber production compared to microtubers derived plants. Ranalli et al. [22] reported that microtubers and minitubers of $\mathrm{cv}$. Monalisa were produced in the laboratory and compared with normal seed tubers in a field experiment. These tubers were planted at similar plant densities $\left(13.6\right.$ sprouts $\left.\mathrm{m}^{-2}\right)$ with two distances between rows $(60$ and $90 \mathrm{~cm})$. Normal seed and minitubers and microtubers yielded, respectively, 50.8, 31.7, and $17.0 \mathrm{tha}^{-1}$ which corroborate with the present findings. In all three varieties, microtuber derived plants produced a minimum percentage of $<28 \mathrm{~mm}$ size of minituber and higher maximum percentage of $28-40 \mathrm{~mm}$ and $>40 \mathrm{~mm}$ size of minituber compared to plantlet derived plants (Figure 3).

\section{Conclusion}

Microtuber using about 250-500 mg size is the best for maximizing minituber yield compared to plantlet. Also, the use of microtubers instead of in vitro plantlets is advantageous as they are easier to store and handle and do not require any acclimatization treatment.

\section{Competing Interests}

The authors have declared that no competing interests exist. 


\section{Authors' Contributions}

This work was carried out in collaboration between all authors. Author Md. Sadek Hossain designed the study, wrote the protocol, and wrote the first draft of the manuscript. Authors M. Mofazzal Hossain and M. Moynul Haque reviewed the study design and all drafts of the manuscript. Authors Md. Mahabubul Haque and Md. Dulal Sarkar performed the statistical analysis and also managed the literature searches. All authors read and approved the final manuscript.

\section{Acknowledgments}

The authors express profound gratitude to the Ministry of Science and Technology, Bangladesh, for financial support during conducting this research.

\section{References}

[1] M. H. Rashid, S. Akhter, M. Elias, M. G. Rasul, and M. H. Kabir, "Seedling tubers for ware potato production: Influence of size and plant spacing," Chinese Potato Journal, vol. 3, pp. 14-17, 1993.

[2] M. Zakaria, M. Hossain, M. K. Mian, T. Hossain, and M. Uddin, "In vitro tuberization of potato influenced by benzyl adenine and chloro choline chloride," Bangladesh Journal of Agricultural Research, vol. 33, no. 3, pp. 419-425, 2008.

[3] E. Baldacci, "Comarzione dei risultati di coltivazione nei primi due annie conclusion realeivel," Genetica Agaria, vol. 14, pp. 213219, 1956.

[4] G. Faccioli and C. Rubies-Autonell, "PVX and PVY distribution in potato meristem tips and their eradication by the use of thermotherapy and meristem-tip culture," Journal of Phytopathology, vol. 103, no. 1, pp. 66-76, 1982.

[5] P. Ranalli, E. Forti, G. Mandolino, and B. Casarini, "Improving production and health of seed potato stocks in Italy," Potato Research, vol. 33, no. 3, pp. 377-387, 1990.

[6] W. M. Roca, N. O. Espinoza, M. R. Roca, and J. E. Bryan, "A tissue culture method for the rapid propagation of potatoes," American Potato Journal, vol. 55, no. 12, pp. 691-701, 1978.

[7] G. Hussey and N. J. Stacey, "In Vitro propagation of potato (Solanum tuberosum L.)," Annals of Botany, vol. 48, no. 6, pp. 787-796, 1981.

[8] G. Wattimena, B. McCown, and G. Weis, "Comparative field performance of potatoes from microculture," American Potato Journal, vol. 60, no. 1, pp. 27-33, 1983.

[9] G. Hussey and N. J. Stacey, "Factors affecting the formation of in vitro tubers of potato (Solanum tuberosum L.)," Annals of Botany, vol. 53, no. 4, pp. 565-578, 1984.

[10] G. Rosell, F. G. De Bertoldi, and R. Tizio, "In vitro mass tuberisation as a contribution to potato micropropagation," Potato Research, vol. 30, no. 1, pp. 111-116, 1987.

[11] E. Forti, G. Mandolino, and P. Ranalli, "In vitro tuber induction: influence of the variety and of the media," Acta Horticulturae, no. 300, pp. 127-132, 1992.

[12] P. C. Struik and W. J. M. Lommen, "Production, storage and use of micro-and minitubers," in Proceedings of the 11th Triennial Coference of the European Association for Potato Research, pp. 122-141, Edinburgh, UK, 1990.

[13] P.-J. Wang and C.-Y. Hu, "In vitro mass tuberization and virus-free seed-potato production in Taiwan," American Potato Journal, vol. 59, no. 1, pp. 33-37, 1982.
[14] D. E. Van der Zaag, "The implication of tissue culture micropropagation for the future of seed potato production system in Europe," in Proceedings of the 11th Triennial Conference of the European Association for Potato Research, pp. 28-45, Edinburgh, UK, 1991.

[15] T. Murashige and F. Skoog, "A revised medium for rapid growth and bio assays with tobacco tissue cultures," Physiologia Plantarum, vol. 15, no. 3, pp. 473-497, 1962.

[16] P. S. Naik and D. Sarkar, "Influence of light-induced greening on storage of potato microtubers," Biologia Plantarum, vol. 39, no. 1, pp. 31-34, 1997.

[17] Anonymous, Fertilizer Recommendation Guide-2012, Bangladesh Agricultural Research Council, Dhaka, Bangladesh, 2012.

[18] M. Zakaria, Induction and performance of potato microtuber [Ph.D. thesis], Bangabandhu Sheikh Mujibur Rahman Agriculture University, Gazipur City, Bangladesh, 2003.

[19] J. Kawakami, K. Iwama, Y. Jitsuyama, and X. Zheng, "Effect of cultivar maturity period on the growth and yield of potato plants grown from microtubers and conventional seed tubers," American Journal of Potato Research, vol. 81, no. 5, pp. 327-333, 2004.

[20] N. Pérez-Alonso, E. Jiménez, M. de Feria et al., "Effect of inoculum density and immersion time on the production of potato microtubers in temporary immersion systems and field studies," Biotecnología Vegetal, vol. 3, pp. 149-154, 2007.

[21] M. S. Islam, Indigenous potato varieties of Bangladesh: characterization by RAPD markers and production of virus free stock [Ph.D. thesis], Bangabandhu Sheikh Mujibur Rahman Agricultural University, Gazipur City, Bangladesh, 1995.

[22] P. Ranalli, F. Bassi, G. Ruaro, P. Del Re, M. Di Candilo, and G. Mandolino, "Microtuber and minituber production and field performance compared with normal tubers," Potato Research, vol. 37, no. 4, pp. 383-391, 1994.

[23] A. J. Haverkort, M. Van De Waart, and J. Marinus, "Field performance of potato microtubers as propagation material," Potato Research, vol. 34, no. 3, pp. 353-364, 1991.

[24] J. H. Dodds, P. Tover, R. Chandra, E. Estrella, and R. Cabello, "Improved methods for in vitro tuber induction and use of in vitro tubers in seed programs," in Proceedings of the Symposium on Improved Potato Planting Material, pp. 157-158, Asia and Pacific Seed Association (APSA), Kunming, China, June 1988. 


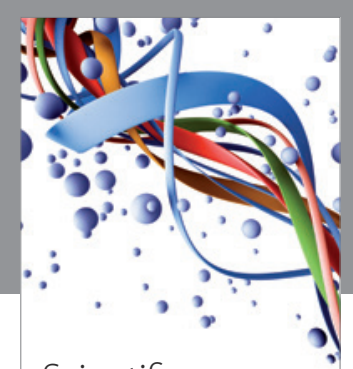

Scientifica
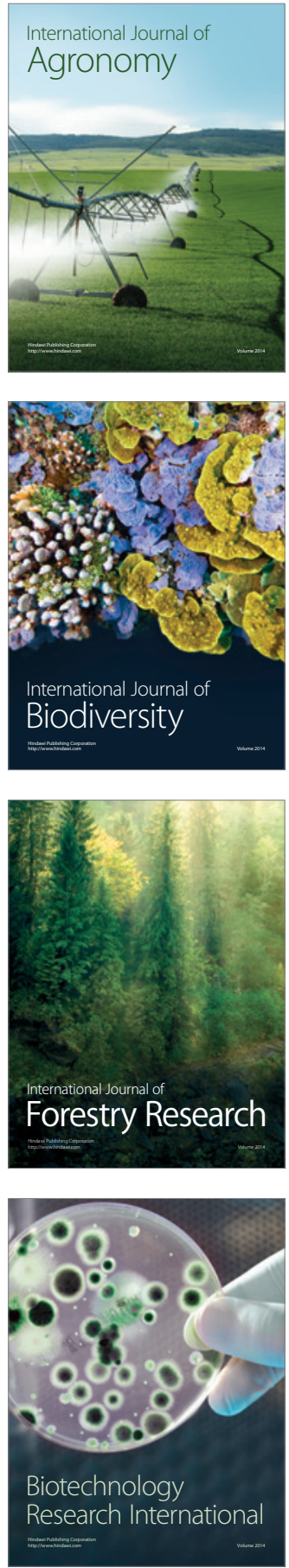
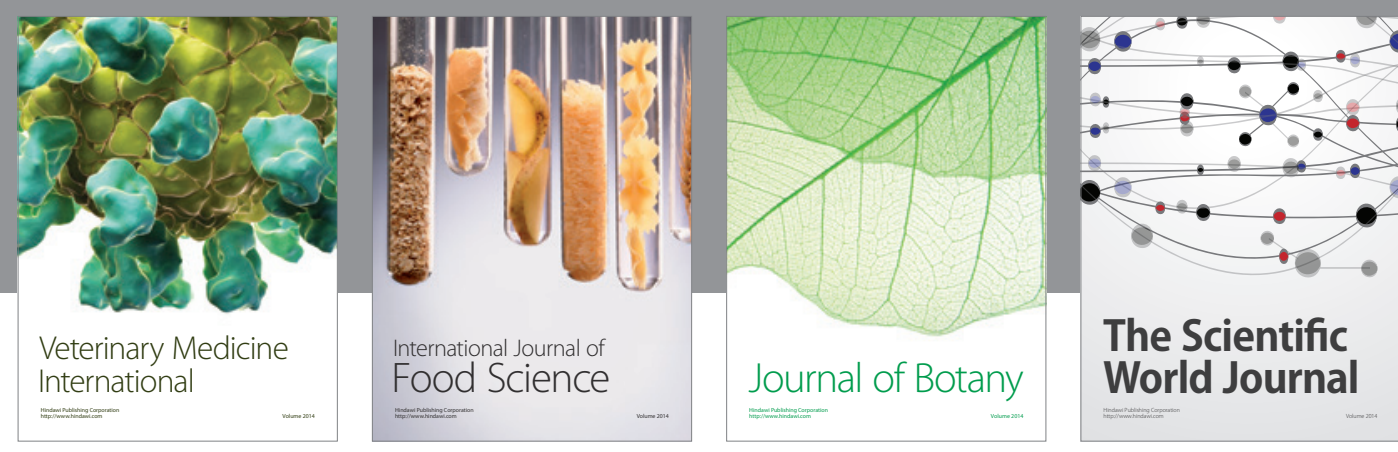

The Scientific

\section{World Journal}

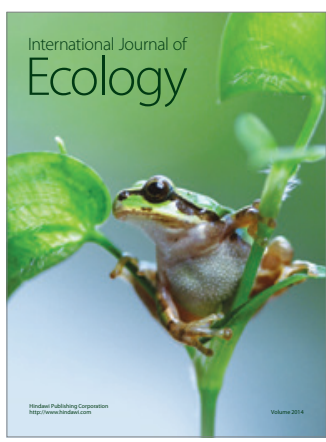

\section{Hindawi}

Submit your manuscripts at

https://www.hindawi.com
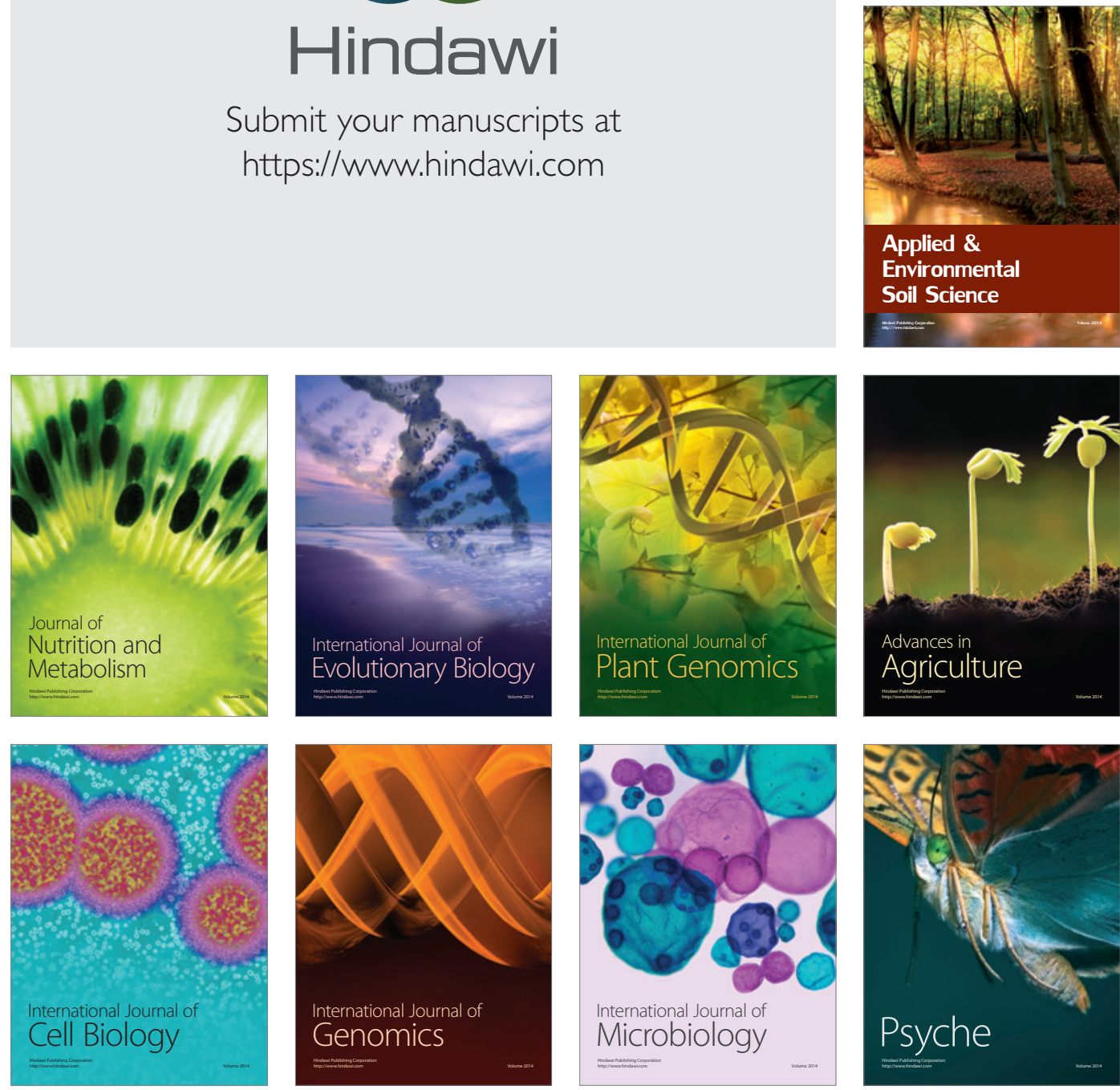
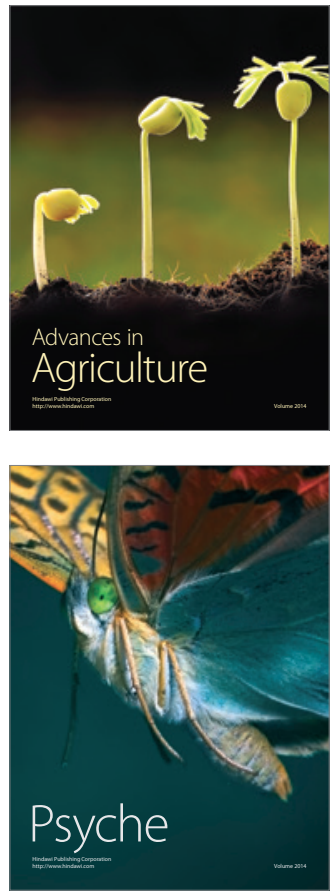